\title{
The Effect of Therapy Music of Natural Sound to Anxiety in the Last Batch Students
}

\author{
$1^{\text {st }}$ Yulisetyaningrum \\ Health Faculty \\ Universitas Muhammadiyah Kudus \\ Indonesia \\ yulisetyaningrum@umkudus.ac.id
}

\author{
$2^{\text {nd }}$ Nurlaily Prasetyawati \\ Health Faculty \\ Universitas Muhammadiyah Kudus \\ Indonesia
}

\author{
$3^{\text {rd }}$ Eka Pratiwi \\ Health Faculty \\ Universitas Muhammadiyah Kudus \\ Indonesia
}

\begin{abstract}
The Anxiety is something that is often felt by students in preparing their thesis or final project. Based on the results of the preliminary survey at the Muhammadiyah Health college Kudus on November 1, 2017 using Hamilton Anxiety Rating Scale questionnaire and the result shows that 4 respondents from 10 respondents experienced severe anxiety, 4 respondents experience moderate anxiety, and 2 respondents experience mild anxiety. The anxiety can be overcome in several ways one of which is anxiety can be done with relaxation therapies such as music and nature sounds. Psychologically, music can make a person more relaxed, reduce anxiety, cause a sense of security and prosperity, release feeling happy and sad, and help and release pain.The study aims to determine the effects of nature sounds music therapy to decreases anxiety to senior college student of Muhammadiyah Health College on Kudus. The study use Quasi-experimental type using pre-test and post-test with control group design. The samples of study consisted of 32 respondents and were taken by using the purposive sampling. Control group of 16 respondents and Intervensi group of 16 respondents. The data were analyzed by Wilcoxon test. The study of the effects of nature sounds music therapy to decreases anxiety to senior college student of Muhammadiyah Health College on Kudus showed $p$ value $=0,006(<0,05)$. There is an effects of nature sounds music therapy to decreases anxiety to senior college student of Muhammadiyah Health College on Kudus.
\end{abstract}

\section{Keywords-Therapy Music, Natural Sound, Anxiety}

\section{INTRODUCTION}

Anxiety is something that is often felt by students in preparing their thesis or final project. The source of anxiety for students in preparing their thesis is the burden of the final project such as not being able to do it, being afraid of the supervisor, lack of support and not being able to understand. It is estimated that around $70 \%$ to $87 \%$ of final year students experience anxiety. The characteristics that appear from student anxiety are the arising of unpleasant feelings and then students consciously feel tension and fear and an increase in autonomic nerves when thinking about the final project so students choose to be reluctant to do the final project [1]. It was reported that the estimated anxiety disorder in America is was around $18.1 \%$ or around 42 million people living with anxiety disorders, such as panic disorder, obsessive-compulsive disorder, post-traumatic stress disorder, generalized anxiety disorder and phobias [2].

In Indonesia the prevalence related to anxiety disorders according to the results of the Basic Health Research (Riskesdas) in 2014 showed that as many as $6 \%$ or around 14 million people in Indonesia experienced mental emotional disorders as indicated by symptoms of anxiety and depression [2]. Research in the university's nursing department Brawijaya, found that of the 62 students who became respondents, $48.4 \%$ (30 people) students experienced mild anxiety, $43.5 \%$ (27 people) experienced moderate anxiety and $8.1 \%$ (5 people) experienced severe anxiety [3]. Based on the results of a preliminary survey conducted by researchers at Muhammadiyah Stikes Kudus on November 1, 2017 using the HARS (Hamilton Anxiety Rating Scale) questionnaire and the results showed that 4 respondents out of 10 respondents experienced severe anxiety, ie individuals tend to think of a final project complained of dizziness, headaches, unable to sleep, confusion, helpless feelings, frequent urination, and stomach pains, 4 respondents experienced moderate anxiety, allowing individuals to think about the final task until fatigue, increased heart rate, increased breathing, no patient, increased muscle tension and 2 respondents experienced mild anxiety, with symptoms of fatigue.

Anxiety can cause physiological changes including blood pressure, heart rate, breathing, agitation, increased muscle activity / movement, fear of threats to an unfamiliar environment with continuous noise, sophisticated technology, loss of privacy, inability to communicate effectively, limited mobility, sleep disturbance. Anxiety management is very important so that it does not turn into fear that can stimulate the sympathetic nervous system, resulting in an increase in respiratory work, oxygen demand, and heart muscle work [4]. How to deal with anxiety can be done with pharmacism and non-pharmacy, one of the nonpharmaceutical therapies using natural sound music therapy. According to the Agency for health research and the quality of health care in Ronchester, Minnesota anxiety can be overcome in several ways one of which is anxiety can be done with relaxation therapies such as music and nature sounds [5]. Nature sounds music is a new type of music due 
to the modernization of sound recording technology, a form of integrative classical music with natural sounds. Sound compositions produced by natural phenomena, such as wind, rain, sea, river, animals, and birds. Natural sounds also have different tempos, pitches, and rhythms that are generally slow or not suddenly high notes. Humans have a close relationship and contact with nature that is beneficial to health [6]. Overall music can affect physically and psychologically. Psychologically, music can make a person more relaxed, reduce anxiety, cause a sense of security and prosperity, release the feeling of joy and sadness, and help and release pain [7].

\section{RESULT AND DISCUSSION}

In this study used quasi-experimental by comparing between intervention and control groups. The research design used pretest-posttest with control group approach. The population in this study were 35 final year undergraduate students of Nursing at health college Muhammadiyah Kudus who experienced anxiety. The sample in this stud were 32 people with 16 control groups and 16 intervention groups. The method of this study to determine samples uses the purposive sampling method. The instrument used the HARS questionnaire. Data in this study were analyzed the Wilcoxon Test analysis.

\begin{tabular}{|c|c|c|c|c|}
\hline \multirow{3}{*}{ Variable } & \multicolumn{4}{|c|}{ Intervention Group } \\
\hline & \multicolumn{2}{|c|}{ Before } & \multicolumn{2}{|c|}{ After } \\
\hline & Frequency & $(\%)$ & Frequency & $(\%)$ \\
\hline There is no & 0 & 0 & 5 & 31,3 \\
\hline Mild & 8 & 50,0 & 7 & 43,8 \\
\hline Moderate & 4 & 25,0 & 3 & 18,3 \\
\hline Severe & 4 & 25,0 & 1 & 6,3 \\
\hline Total & 16 & 100,0 & 16 & 100,0 \\
\hline
\end{tabular}

Table I shows that before performing music therapy of natural sound experienced anxiety obtained as many as 8 respondents $(50.0 \%)$ mild anxiety, 4 respondents $(25.0 \%)$ moderate anxiety, and 4 respondents $(25.0 \%)$ experienced severe anxiety, however, after natural music music therapy was reduced by 5 respondents $(31.3 \%)$ there was no anxiety, 7 respondents $(43.8 \%)$ mild anxiety, 3 respondents $(18.3 \%)$ moderate anxiety, and 1 respondent $(6.3 \%)$ experience severe anxiety. Based on the table above, it be seen that the intervention group changes anxiety levels.

TABLE II. FREQUENCY DISTRIBUTION BASED ON ANXIETY LEVEL BEFORE AND AFTER PERFORMING NATURAL SOUND MUSIC THERAPY IN THE CONTROL GROUP

\begin{tabular}{|l|c|c|c|c|c|}
\hline \multirow{3}{*}{ Variable } & \multicolumn{3}{|c|}{ Intervention Group } & p Value \\
\cline { 2 - 5 } & \multicolumn{2}{|c|}{ Before } & \multicolumn{2}{c|}{ After } & \\
\cline { 2 - 5 } & Frequency & $(\%)$ & Frequency & $(\%)$ & \\
\hline There is no & 0 & 0 & 5 & 31,3 & \\
\hline Mild & 8 & 50,0 & 7 & 43,8 & \\
\hline Moderate & 4 & 25,0 & 3 & 18,3 & \\
\hline Severe & 4 & 25,0 & 1 & 6,3 & \\
\hline Total & 16 & 100,0 & 16 & 100,0 & \\
\hline
\end{tabular}

In table II. shows that in the control group before doing music therapy of natural sound that experienced anxiety there were 5 respondents $(31.3 \%)$ mild anxiety, 6 respondents $(37.5 \%)$ moderate anxiety, and 5 respondents $(31.3 \%)$ experiencing severe anxiety, but after doing natural sound music therapy in the intervention group, the control group experienced an increase in anxiety by 4 respondents (25.0\%) mild anxiety, 7 respondents $(43.8 \%)$ moderate anxiety, and 5 respondents $(31,3 \%)$ experience severe anxiety. From this data it appears that the control group experienced increased anxiety 
TABLE III. DIFFERENCES BETWEEN BEFORE AND AFTER TREATMENT OF UNDERGRADUATE NURSING STUDENTS AT STIKES MUHAMMADIYAH KUDUS IN 2018

\begin{tabular}{|l|c|c|c|c|c|}
\hline \multirow{3}{*}{ Variable } & \multicolumn{4}{|c|}{ Intervention Group and Control Group } & $\begin{array}{l}\text { Asymp. Sig. (2- } \\
\text { tailed) }\end{array}$ \\
\cline { 2 - 5 } & After The Intervention & After Control & 0,006 \\
\cline { 2 - 5 } & Frequency & $(\%)$ & Frequency & $(\%)$ & \multirow{2}{*}{} \\
\hline There is no & 5 & 31,3 & 0 & 0 & \\
\hline Mild & 7 & 43,8 & 4 & 25,0 & \\
\hline Moderate & 3 & 18,3 & 7 & 43,8 \\
\hline Severe & 1 & 6,3 & 5 & 100,0 & \\
\hline Total & 16 & 100,0 & 16 & & \\
\hline
\end{tabular}

\section{A. Intervention Group}

The results of the analysis of differences in the level of anxiety between before and after treatment $t$ ) in the intervention group, obtained $p$ value of $0.001<\alpha(0.05)$, thus
Ho is rejected and Ha is accepted, which means "There is an effect of therapy music of natural sound on anxiety at the end of S1 level students nursing Science".

TABLE IV. INTERVENTION GROUP

\begin{tabular}{|l|c|c|c|c|}
\hline \multirow{2}{*}{ Variable } & \multicolumn{4}{|c|}{ Control Group } \\
\cline { 2 - 5 } & \multicolumn{2}{|c|}{ Before } & \multicolumn{2}{c|}{ After } \\
\cline { 2 - 5 } & Frequency & $(\%)$ & Frequency & $(\%)$ \\
\hline Mild & 5 & 31,3 & 4 & 25,0 \\
\hline Moderate & 6 & 37,5 & 7 & 43,8 \\
\hline Severe & 5 & 31,3 & 5 & 100,0 \\
\hline Total & 16 & 100,0 & 16 & \\
\hline
\end{tabular}

\section{B. Control Group}

The control group experienced an increase in frequency $p$ value of $0.0658>\alpha(0.05)$, thus Ho was accepted and Ha was rejected, which means there was no effect when music therapy was not given to the control group.

Anxiety is a shocking situation because of a threat to health. Individuals who are classified as normal sometimes experience anxiety that appears, so that it can be witnessed in the form of physical and mental symptoms [11]. Overall music can affect both physically and psychologically. Psychologically, music can make a person more relaxed, reduce anxiety, cause a sense of security and well-being, release joy and sadness, and help and release pain [8]. According to the Health Research and Health Care Agency in Ronchester, Minnesota anxiety can be overcome in several ways, one of which is anxiety can be done with relaxation therapy such as music and nature sounds [5]. This is in line with Rosma's research on the effect of positive thinking to reduce anxiety in students who are taking thesis with the results of $p=0.002(P<0.05)$ [12]. Besides the use of music therapy based on clinical and evidence based can increase individuals in therapeutic relationships with someone so that it can reduce stress and anxiety [13].

TABLE V. MANN-WHITNEY TEST RESULTS DIFFERENCES IN ANXIETY BEFORE AND AFTER TREATMENT FOR UNDERGRADUATE NURSING STUDENTS AT FINAL STIKES MUHAMMADIYAH KUDUS IN 2018

\begin{tabular}{|l|c|c|c|c|c|}
\hline \multirow{3}{*}{ Variable } & \multicolumn{3}{|c|}{ Control Group } & p Value \\
\cline { 2 - 5 } & \multicolumn{2}{|c|}{ Before } & \multicolumn{2}{c|}{ After } & 0,0658 \\
\cline { 2 - 5 } & Frequency & $(\%)$ & Frequency & $(\%)$ & \multirow{2}{*}{} \\
\hline Mild & 5 & 31,3 & 4 & 25,0 \\
\hline Moderate & 6 & 37,5 & 7 & 43,8 \\
\hline Severe & 5 & 31,3 & 5 & 31,3 & \\
\hline Total & 16 & 100,0 & 16 & 100,0 & \\
\hline
\end{tabular}

The results showed that in the control group before doing natural sound music therapy that experienced anxiety there were 5 respondents $(31.3 \%)$ mild anxiety, 6 respondents $(37.5 \%)$ moderate anxiety, and 5 respondents $(31.3 \%)$ experienced severe anxiety, but after doing natural sound music therapy in the intervention group, the control group experienced an increase in anxiety by 4 respondents $(25.0 \%)$ mild anxiety, 7 respondents $(43.8 \%)$ moderate anxiety, and 5 respondents $(31.3 \%)$ experiencesevere anxiety. From this data it appears that the control group experienced increased anxiety. 
From the data above it can be seen that the average in the control group experienced moderate anxiety, because respondents in the final year students often felt anxious and anxious, too depressed when the supervisor was difficult to find, difficulties in data management, limited time constraints so that respondents in the control group experience a moderate increase in anxiety.

In this study, the intervention group and the control group were both given a questionnaire before doing natural sound music therapy. This is done to compare the effects of natural sound music therapy which is more significant.

The results showed that there was an effect of natural sound music therapy on anxiety reduction in the final year S1 undergraduate nursing at the Stikes Muhammadiyah Kudus. Music can increase creativity, build self-confidence, develop social skills, and improve motor skills, perception, and psychomotor development, music can also be used as a therapy for various needs [9]. Nature sound music therapy is music and nature sounds (nature sound) [5]. Nature sounds music is a kind of new discovery music due to the modernization of sound recording technology, an integrative form of classical music with natural sounds. Sound compositions produced by natural phenomena, such as wind, rain, sea, river, animals, and birds. Natural sounds also have different tempos, pitches, and rhythms that are generally slow or not suddenly high notes. Humans have a close relationship and contact with nature that is beneficial to health [6]. Music gives a nuance that is entertaining, fostering a soothing and pleasing atmosphere, so that music does not only affect the intelligence of thinking alone but also emotional intelligence [10].

From the results of the Wilcoxon analysis it was found that $p$ value $0.001<\alpha(0.05)$ in the intervention group and $p$ value $0.0658>\alpha(0.05)$ in the control group. This shows that there are significant changes in the intervention group compared to the control group. Thus, Ho is rejected and Ha is accepted, which means that there is an influence of Natural Sound Music Therapy on Reduction of Anxiety in Final Year S1 Nursing Students of STIKES Muhammadiyah Kudus.

To find out whether there are differences in anxiety levels after treatment (post-test) of natural sound music therapy in the intervention group, the final observation (post-test) in the control group uses the Mann-Whitney statistical test. Based on the results of the significance obtained $\mathrm{p}=0.006<0.05$ shows that the data are homogeneous, while the significance of the 2 tailed t-test results obtained $\mathrm{p}=0.004<0.05$ indicates that there is a significant difference of $5 \%$.

\section{CONCLUSION}

There is an Effect of Natural Sound Music Therapy on Decreased Anxiety in Final Level Students of STIKES Muhammadiyah Kudus with a $p$ value of $0.001<\alpha(0.05)$. There is a difference with a significant average of anxiety reduction after being treated in the control and intervention groups with $\mathrm{p}$ value $=0.006<0.05$, indicating that there is a significant difference of $5 \%$.

\section{ACKNOWLEDGMENT}

I would like to thank to Muhammadiyah University of Kudus for both material and financial support for completing this research.

\section{REFERENCES}

[1] Herdiani, W. S. Pengaruh Expressive Writing Pada Kecemasan Menyelesaikan Skripsi. Jurnal Mahasiswa Universitas Surabaya Vol.1 No.1, 2012

[2] Duckworth, A. L., Grit: Perseverance and Passion for Ling-Term Goals. Journal of Personality and Social Psychology, 92(6), 10871101. 2009

[3] Kemenkes RI. Laporan Hasil Riset Kesehatan Dasar (Riskesdas) Indonesia tahun 2014. Jakarta: Badan Penelitian dan PengembanganvKesehatan Kemenkes RI; 2014

[4] Siregar, C. N. Tingkat Kecemasan Pada Santri Pondok Pesantren. Vol. 01 No. 01, Tahun. 2013. Jurnal Online Psikologi Universitas Muhammadiyah Malang. 2013

[5] Chlan, L., \& Savik, K. NIH Public Access: Pattern of anxiety in critically ill patients receiving mechanical ventilatory support, 60(Mv), 1-17. http://doi. org/10.1097/N NR.0b013e 318216009c.Patterns, 2011

[6] Cutshall, S. M., Olney, T. L., Messner, P. K., Brekke, K. M., Iii, T. M. S., Kelly, R. F., \& Bauer, B. A.. Effect of the combination of music and nature sounds on pain and anxiety in cardiac surgical patients: A Randomized Study, 17(4), 16-24, 2011

[7] Chiang, et all. The effects of music and nature sounds on cancer pain and anxiety. Disertasi. 2012

[8] Djohan. Terapi Musik Teori dan Aplikasi. Yogjakarta: Galangpress. 2009

[9] Utama, S, W., \& DKK. Pengaruh Terapi Musik Alam Terhadap Frekuensi Denyut Jantung Pada Pasien Selama Operasi Dengan Anestesi Spinal Di RSUD PANDAN ARANG BOYOLALI. Naskah Publikasi Sekolah Tinggi Ilmu Kesehatan Kusuma Husada, Surakarta. 2017

[10] Wisnu Haruman. Pengaruh Terapi Musik Terhadap Penurunan Kecemasan Atlet Anggar Sebelum Menghadapi Pertandingan. Skripsi.Bandung: Fakultas Pendidikan Olahraga danKesehatan UniversitasPendidikan Indonesia. 2013

[11] Wijayanti, K. Musik Suara Alam Terhadap Penurunan Kecemasan Pada Pasien Kritis. Nurscope. Jurnal Keperawatan dan Pemikiran Ilmiah. 2016

[12] Manurung, Nixson. Terapi Reminiscence "Solusi pendekatan sebagai upaya tindakan keperawatan dalam menurunkan kecemasan,stress dan depresi”. Jakarta: Cv. Trans Info Media. 2016

[13] Rosma, S. Pengaruh Pelatihan Berpikir Positif Untuk Menurunkan Kecemasan Pada Mahasiswa Yang Sedang Menempuh Skripsi. Jurnal Psikologi Universitas Ahmad Dahlan. 2013

[14] American Music Therapy Association. Music therapy mental health -evidence based practice support. (http://www.music_therapy.org/factsheet/b.b.psychopathology.pd f). 2008 